\author{
Kamil Kowalski \\ University of Lodz, \\ Institute of Economics \\ e-mail: kamil.kowalski@uni.lodz.pl
}

\title{
What Shall We Do with Our Boys? An Impact of the GI Bill on the US Economy
}

\begin{abstract}
The GI Bill of Rights (The Servicemen's Readjustment Act of 1944) was a comprehensive program to aid returning veterans in their speedy readjustment to a civilian life. Its role was also to enable the veterans to fit them into the civilian economy. In the first part of the text, the economic and political context of the discussion around the Bill is discussed. The author refers to the popular belief that the end of the war was expected to result in the return of another economic depression. The latter was to be deepened by winding down war production and speeded up by returning servicemen. The text examines how the Bill was to tackle that challenge. The main body of the article is built around the analysis of the provisions of the Act that relate to the benefits for the former soldiers. This includes a mustering-out pay, education benefits, medical care for the disabled in the war, unemployment insurance, an allowance credit and pensions for disabled veterans. The requirements, terms of funding and sum of benefits are presented and discussed. The last part concludes with the general remarks about the significance of the Bill and its contemporary perception in the USA.
\end{abstract}

Keywords: conversion, GI Bill, Post-war economy, Roosevelt

JEL Classification: I24, N32, N42 


\section{Introduction}

Public programs for veterans enjoyed a long, established history in the United States. For instance, after the Civil War, the largest unit within the federal budget expenditure was aimed at the benefits to this special group. ${ }^{1}$ This American tradition of appreciation towards demobilised veterans was repeated after World War II again. The Servicemen's Readjustment Act of 1944, commonly known as the GI Bill of Rights, was an attempt of a comprehensive approach to demobilisation, and as such, was the most expensive and the most ambitious plan to absorb the millions of demobilised soldiers by the booming US economy. ${ }^{2}$ One of the many intentions guiding the creators of the Act was the will not to repeat errors from the period after World War I when the US authorities lacked imagination, and veterans were offered $\$ 60$ and a train ticket home. ${ }^{3}$ It is important to emphasise that after 1941 the scale of demobilisation was much greater: compared to the Great War the number of Americans participating in hostilities quadrupled (from four to sixteen million). Still on the day of Japan's surrender 12.1 million Americans continued to serve in the armed forces, accounting for 2/3 of men aged 18-34 years. Such were the challenges that American leaders faced in the forties. The aforementioned Act was an attempt to solve the expected problems in advance.

This article describes the circumstances of the adoption of one of the most important American legislation on social issues. It outlines the main axes of the dispute while passing the Bill in Congress and points to concerns accompanying the adoption of innovative regulations. The paper discusses the most important areas of assistance provided for by the Act, the conditions required to receive benefits, the amount and duration of benefits. My intention was also to identify gaps and weaknesses in the Bill and in the last part of the article to assess it. In the paper, I try to show that the Bill was a successful attempt to handle the millions of returning servicemen and contributed greatly to American economic and social development. The method used to investigate the thesis is based on a critical analysis of the primary sources (the text of the Bill and the official brochure) and major works on the post-war US demobilisation policies.

\footnotetext{
${ }^{1}$ I.M. Conesa, A.D. Rubio, The Consequences of a Forced Migration: The Return Home of WWII American Veterans, “Advances in Historical Studies" 2016, Vol. 5, p. 36.

${ }^{2}$ The Servicemen's Readjustment Act of 1944 (PL 78-346), see: United States Statutes at Large, United States Printing Office, Washington 1945, pp. 284-300.

${ }^{3}$ Payment of appropriate bonuses was postponed. This policy, coupled with the great crisis of 1929-1932, entailed the so-called Bonus March of 1932 in which more than 40,000 demonstrators took part, including 20,000 veterans. To stop the riots, President Herbert Hoover used the army. Incidentally, it was the first use of federal forces against former US soldiers in the country. On the government side, later American heroes took part: Douglas MacArthur, Dwight Eisenhower and George Patton. (see more: P. Dickson, T.B. Allen, The Bonus Army. An American Epic, Walker and Company, New York 2004).
} 


\section{A way to pass the Bill}

Even in the middle of the US military struggles, on May 27, 1943 Franklin D. Roosevelt appealed to Congress to help future veterans: 'We have taught our youth how to wage war; we must also teach them how to live useful, and happy lives in freedom, justice and decency. ${ }^{4}$ In one of his chats by the fireplace (July 28, 1943) he indicated that the returning soldiers cannot come to the country consumed by inflation and unemployment and live at the bread line 'selling apples on the corner.' Instead, Roosevelt proposed a six-point package of assistance to demobilised soldiers. The list included a mustering-out pay, education benefits, medical care for the disabled in the war, unemployment insurance, an allowance credit and pensions for disabled veterans. ${ }^{6}$ Unlike the years before the Bill was to be ready on time, and not at the last minute and due to that with flaws. ${ }^{7}$ The president's six-point program brought a rush of congressional endorsements. Numerous earlier initiatives of the Congress ended in failure. ${ }^{8}$ The intended target has been achieved, not without difficulties and most of the declared solutions have been included in the final draft of the project. President Roosevelt signed the Bill into law on June 22, 1944, just five months after the project found its way to Congress during the gigantic invasion of Normandy, which was also symbolic. ${ }^{9}$

The final shape of the regulation and a fast-track legislation were largely the result of effective lobbying by the most important combatant organisation, i.e. the American Legion, which in the Autumn of 1943 launched a campaign in favour of the bill for soldiers returning from the war. ${ }^{10}$ Opposition to the proposed bill was focused on a possible waste of public funds. Certain sceptical congressmen predicted that benefits will foster a delay in returning to work, especially as their potential beneficiaries - because of the great crisis of the 1930s - were not accustomed to working full-time. In turn, deputies from the South opposed the same provisions for whites and blacks. John Rankin, the Chairman of the Committee on Veterans' Affairs in the House of Representatives and at the same time supporter of racial segregation from Mississippi, was a particularly firm opponent of the introduction

\footnotetext{
${ }^{4}$ Public Papers of the Presidents of the United States, Vol. 12, 1943, p. 451.

5 Ibidem, p. 333.

${ }^{6}$ Ibidem.

${ }^{7}$ In this spirit, Willard Waller entitled a chapter of his book about helping veterans: 'Not to plan now, is to plan a disaster' (W. Waller, The Veteran Comes Back, Dryden, New York 1944, p. 247).

${ }^{8}$ By the fall of 1943, Congress submitted 640 bills regarding veterans' affairs (I.M. Conesa, A.D. Rubio, op. cit., p. 39).

${ }^{9}$ The bill was introduced in the House and the Senate on January 10-11, 1944, but both chambers approved their own versions of the regulation. Both chambers agreed on the education and home loan provisions but were deadlocked on the unemployment benefits. Finally, the bill was unanimously approved by the House of Representatives on June 9, 1944, and by the Senate on June 12-13, 1944. More information about the course of voting in the Committee of the Chamber of Representatives see: H.M. Mason, VFW: Our First Century, Addax Publishing Group, Lenexa 1999, p. 110.

${ }^{10}$ In November 1943, the American Legion formed a committee, headed by John H. Stelle to draft a bill for readjustment of the veterans of the War. Another key role in formulating the provisions of the Bill played a former president of the Legion, Harry W. Colmery - the author of the first draft of the GI Bill.
} 
of provisions on equality of benefits, regardless of skin colour. ${ }^{11}$ Eventually, the shape of the adopted bill did not contain provisions which discriminate against minorities. The functioning of the regulation left no doubt, however, about the actual policy of racial segregation in post-war America. ${ }^{12}$ In this sense, Michael Bennett's assessment of the GI Bill as a 'color-blind social legislation,' seems inaccurate. ${ }^{13}$

The legitimacy of regulations adopted in the GI Bill of Rights was confirmed in the very pace of demobilisation - after Japan's capitulation an average of 100,000 soldiers per month were discharged from service. The slogan 'no boats, no votes' was in fashion, as an expression of the pressure on politicians to opt in favour of speeding up demobilisation. In total, there were 3 million men in uniform by the end of 1946 and only 545,000 in 1948.

It should be emphasised that the GI Bill of Rights was as much an expression of gratitude and atonement for the soldiers fighting for American interests, but also - and perhaps primarily - an instrument of national economic policy. Sixteen million demobilised soldiers were treated as the source of a potential outbreak of discontent. On the other hand, important were the expectations of the American people, to regulate the influx of millions of potential workers, particularly in the context of recent reminiscence of unemployment in the 1930s. American society felt a sense of ambivalence manifested in the sense of joy about the nearing end of a long, debilitating war (hence the spontaneous joy after the capitulation of Japan), but also anxiety before the next crisis. There was widespread concern about the destruction of the effects of the war economic boom by the returning excessive number of 'working hands' coupled with the decreasing (which was wrongly predicted) supply of jobs. ${ }^{14}$ Finally, the proponents of the regulation raised an important psychological factor: the situation and prospects of those returning from the war should not be worse than for those who had remained in the country during the war. ${ }^{15}$

All these possible dilemmas and difficulties were indicated back in April 1942 by Eleanor Roosevelt, warning against creating 'a dangerous pressure group in our midst. ${ }^{\text {" }}$ These emotions - focused around the return of the spectre of mass unem-

\footnotetext{
${ }^{11}$ M.D. Van Ells, To Hear Only Thunder Again. America`s World War II Veterans Come Home, Lexington Books, Oxford 2011, p. 30.; Cf. H. Herbold, Never a Level Playing Field: Blacks and the GI Bill, "The Journal of Blacks in Higher Education" 1994, Vol. 6, p. 104. ("Senator John Rankin, a Democrat from Mississippi, was notorious for his prosegregationist and racist position on all issues relevant to blacks').

${ }^{12}$ According to a survey conducted by scholar Howard Johnson in one southern state only seven of 1,700 veterans employed by the VA were Negroes. H. Johnson, The Negro Veteran Fights for Freedom!, "Political Affairs" 1947, No. 5, p. 430.

${ }^{13}$ M. Bennett, When Dreams Came True: The GI Bill and Making of Modern America, Brassey 2000, p. 26.

${ }^{14}$ E. Humes, Over Here. How the G. I. Bill Transformed the American Dream, Harcourt, New York 2006, p. 12.

${ }^{15}$ Roosevelt drew attention to this aspect at the signing of the Bill: 'They have been compelled to make greater economic sacrifice and every other kind of sacrifice than the rest of us, and are entitled to definite action to help take care of their special problems.' Quoted after: S.C. Tucker, World War II. The Definite Encyclopedia and Document Collection, Vol. 2, ABC-CLIO, Santa Barbara 2016, p. 2234.

${ }^{16}$ Quoted after: S.R. Ortiz, Beyond the Bonus March and GI Bill. How Veteran Politics Shaped the New Deal Era, New York University Press, New York 2010, p. 198.
} 
ployment - were heated up by the press, mainly concentrated in the hands of William Hearst. ${ }^{17}$ Because of these concerns, the laws preceding the GI Bill of Rights and which were to regulate, although fractionally, the issue of demobilization, pointed to labour issues as the most important and therefore subject to regulation in the first place. ${ }^{18}$

\section{Main provisions of the Bill}

The Act provided for the four areas of assistance for returning soldiers: education, loans, benefits and help in finding employment. The system of benefits, which had been restricted to disabled veterans following World War I, was abandoned. ${ }^{19}$ The Bill was democratic in the sense that it did not differentiate benefits depending on the military rank, skin colour or wealth. The principle was adopted that one could not simultaneously use the cash benefits (e.g. a living benefit and unemployment benefit), but one could use non-monetary benefits (e.g. state loan guarantees and unemployment benefits). The Administration of Veterans Affairs (VA) coordinated the program.

Of particular importance were the provisions relating to soldiers' education. The provisions were conceptually based on the solution used locally by the state of Wisconsin (Soldier Educational Bonus), which after the First World War provided numerous free educational benefits to veterans. ${ }^{20}$ The regulations of 1944 introduced the distinction between soldiers entering the service (after September 25, 1939, and lasting at least 90 days or less in the case of injury on the battlefield), aged at least 25 years of age and younger. ${ }^{21}$ In the case of the first group it was required to demonstrate that participation in the war resulted in the termination of a previously initiated learning (without meeting this requirement, a former soldier was entitled to one free year of education). ${ }^{22}$ In relation to the younger soldiers it was assumed that the war disrupted their educational process. One could apply for educational benefits within two

\footnotetext{
${ }^{17}$ Emphasizing the fear of the return of unemployment on the one hand, the Hearst corporation simultaneously supported the activities of the American Legion in favour of new legislation in the area of soldiers returning from service.

${ }^{18}$ On September 16, 1940 Congress passed the Selective Training and Service Act (PL 76-783) which introduced recruitment in peacetime ensuring jobs for conscripts after leaving the service. Veteran's Preference Act of 1944 (PL 78-359) required the federal government to apply the policy of preferential employment for returning military (including widows and wives of disabled veterans).

${ }^{19}$ Four veterans' organisations, i.e. The Veterans of Foreign Wars, Disabled American Veterans, Military Order of the Purple Heart and the Regular Veterans Association, opposed this provision, pointing out that 'the disabled were not sharing properly in the benefits.' T.R. Mosch, The GI Bill: A Breakthrough in Educational and Social Policy in the United States, Exposition Press, New York 1975, p. 41.

${ }^{20}$ The Bill of 1944 was based on other solutions already taken into account in the Soldier Educational Bonus, including the definition of a military veteran and determining the minimum length of service entitling to benefits. S.M. Thomas, Education in Wisconsin 1922-1924, Callahan, Wisconsin 1924, pp. 174-176.

${ }^{21}$ The Bill of Rights and How It Works, Army Times, Washington 1944, pp. 2-16.

${ }^{22}$ The concept of interrupted education was given a broad interpretation, e.g. the necessity to continue the same field of study after the war was not required anymore.
} 
years from the end of the war. The time of their collection could not go beyond the seven-year period after the formal end of the war. ${ }^{23}$ Generally, the program financed education for no longer than four years. This period was dependent on the number of years of military service on the basis of one year plus the number of years of service (but not longer than the aforementioned limit of four years). Then the federal budget covered expenses for tuition, books, fees for use of the library, laboratories (and their equipment), healthcare and other expenses. This pool - not exceeding $\$ 500$ a year did not include the costs of transport and maintenance. There was a separate monthly allowance for living expenses of 50 or 75 dollars (if one had dependents, while the number did not affect the amount of the allowance) $)^{24}$. It was subject to reduction if one attended part-time courses or during the apprenticeship. It should be emphasised that the amount of benefits provided for by the Bill was large enough to cover the entire costs of receiving education. In 1945 annual tuition fee for non-veterans at Harvard was $\$ 400$.

Veterans could apply to educational institutions (from primary school to universities), approved by the Administration of Veterans Affairs or other state agencies. Educational institutions were free to formulate criteria for recruitment but demobilised soldiers did not have a guarantee that they would be admitted to the school. The program, therefore, contained a good deal of liberal values: veterans chose any school where they wanted to be educated (52\% of all World War II college students chose private institutions). ${ }^{25}$ These in turn arbitrarily decided to accept or reject the application.

As it turned out, the universities generally willingly admitted the candidates, which entailed the multiplication (two-three times) of the number of the enrolled. For instance, Harvard's enrolment almost doubled in 1946 from 2,750 in February to 5,000 in September. ${ }^{26}$ Most educational institutions wanted to make up for the weak war years when consecutive enrolments were small. In 1948 ten universities enrolled more than 20,000 students in the first year of study. ${ }^{27}$ This required some compromises: due to the greatly increased enrolment classrooms turned out to be too small, in addition, there was a shortage of teachers. With time classes began to be taught by inexperienced graduates. It was necessary to extend working hours in universities. The presence of spouses and children was a completely new experience on usually temporarily expanded campuses. ${ }^{28}$ To accommodate everybody, it was often necessary to resort to makeshift solutions. Veterans lived in campsites (known as Vetsville or Fertile Acres), and stayed in trailers, i.e. the aim was to provide nomadic students with shelter, even if temporary.

\footnotetext{
${ }^{23}$ The Amended GI Bill of Rights, (PL 79-268) of December 22, 1945, lengthened this period to 9 years. The text of the Bill, see United States Statutes at Large, Washington 1946, pp. 623-632.

${ }^{24}$ After the amendment of December 28, 1945, it was respectively $\$ 65$ (since 1948 the amount increased to $\$ 75$ ) and $\$ 90$.

${ }^{25}$ M. Bennett, op. cit., p. 18.

${ }^{26}$ Ibidem.

${ }^{27}$ For comparison, in 1967, there were 55 such universities (D. Ravitch, The Troubled Crusade. American Education 1945-1980, Basic Books, Washington 1983, p. 15).

${ }^{28}$ In 1947 out of the 30,000 students of the University of Minnesota $60 \%$ were veterans and $32 \%$ of them had a family (W.L. O'Neill, American High. The Years of Confidence 1945-1960, The Free Press, New York 1986, p. 11).
} 
There were voices against the liberal rules for admission of students. The President of the University of Chicago, Robert M. Hutchins, was concerned that schools would not be able to resist the temptation of easy money, sacrificing the level of education on the altar of higher income. Due to the patriotic context of the program, they would resign - warned Hutchins - from the selection both at the recruitment stage and during the very course of education. They will find themselves converted into educational hobo jungles. He found it outrageous to use education as a 'substitute for a dole or for a national program of public works. ${ }^{29}$ President Hutchins went so far as to say that the bill would demoralise education and defraud the veteran. As it turned out, the concerns about the decline in the level of studies, voiced by James B. Conant, the President of the University of Harvard, and from which he had to retract, proved unfounded, and certainly were an overstatement. ${ }^{30}$ As noted by Diane Ravitch - an American educational policy analyst - essentially, in terms of scientific achievements, the veterans were ahead of students without war experience. They enjoyed an enviable reputation as a hardworking people and extremely motivated. ${ }^{31}$

The privilege of free education under the GI Bill of Rights have been used by 64,000 out of 350,000 (18\%) eligible women. Despite this, their number in universities was relatively low. Women accounted for 720,000 of the 2.3 million of those commencing studies in $1950 .^{32}$ In 1940 the percentage of women as students in college was 40 percent while by 1947 , that percentage dropped to 29 percent. ${ }^{33}$ It shows that GI Bill typically benefited men, not women. People were buying private dwellings on a large scale, building houses, often in the suburbs, which ultimately favoured giving up employment and staying to protect hearth and home. Whilst the war fostered the increased participation of women in the US labour market, the first post-war decades brought a reversal of this trend. ${ }^{34}$ It is characteristic that many of the colleges, which before the war had enrolled only women, were transformed into co-educational institutions after 1945. Therefore, the achievements of the GI Bill of Rights in the field of the educational emancipation of women were limited.

The democratisation of education helped erase prejudices: veterans of Jewish origin gained easier access to schools, their enrolment in some schools was limited by quotas. ${ }^{35}$ Racial desegregation has been far less successful. In 17 Southern states

\footnotetext{
${ }^{29}$ R.M. Hutchins, The Threat to American Education, "Collier`s Weekly", December 30, 1944.

${ }^{30}$ Conant argued to adopt an option in which universities would recruit 'carefully selected veterans returning from the war.' (M. Boulton, Failing our Veterans. The GI Bill and the Vietnam Generation, New York University Press, New York 2014, p. 172). In 1946, he acknowledged, however, that the veterans were 'the most mature and promising students in the history of Harvard' (quoted after: J.G. Hershberg, James B. Conant. Harvard to Hiroshima and the Making of the Nuclear Age, Stanford University Press, California 1993, p. 403).

${ }^{31}$ D. Ravitch, op. cit., p. 14.

${ }^{32}$ J. Patterson, Great Expectations. The United States 1945-1974, Oxford University Press, Oxford 1996, p. 367.

${ }^{33}$ J. Blair, GI Bill Paved the Way for a Nation of Higher Learners, "Education Week" 1999, Vol. 18, Issue 20, p. 32.

${ }^{34}$ In a questionnaire experiment carried out in the Air Force on the postwar ambitions of Women Army Corps, 73 percent declared they wanted marriage and home-making (D. Higgins, After the Army - what - Women in Uniform Ask?, Washington News Digest as cited in the Appendix to the Congressional Record, Vol. 91, part 13, $79^{\text {th }}$ Congress, Washington 1947, pp. A-5369).

${ }^{35}$ W. Smith, T. Bender, American Higher Education Transformed, 1940-2005 Documenting the National Discourse, The Johns Hopkins University Press, Baltimore 2008, p. 394.
} 
and the District of Columbia schools were still divided because of the colour of the skin. American researcher Hilary Herbold pointed that 'the University of Pennsylvania, by no means the most elitist of the Ivy League universities, included among its 9,000 students only 46 blacks in 1946.'36

Area of education turned out to be the biggest success of the GI Bill of Rights. In 1940 only $33 \%$ of the 75 million Americans over the age of 25 years had a level of education above the $8^{\text {th }}$ grade. $25 \%$ graduated from high school. Only one in 20 representatives of this age group graduated from a college or university. Only $49 \%$ of seventeen-years-olds held a high school diploma (the war negatively affected this index - in 1946 it fell to 47.4\%). ${ }^{37}$ But already in 1947 (approx. 1 million) veterans accounted for $49 \%$ of students in American colleges. It is worth noting that these figures were a complete surprise for the rulers. It was expected that after leaving the battlefield veterans would be more likely to abstain from knowledge at the secondary and university level. ${ }^{38}$ Meanwhile, until 1956, when the period of application of the Bill expired, up to 7.8 million (about half) of the former soldiers, benefited from the support in education ${ }^{39}$ with 2.2 million attending colleges (97.1\% were males), 3.5 million in vocational schools, and 2.2 million benefitting from a variety of vocational courses (of which 700,000 were in agriculture). ${ }^{40}$ A small percentage studied abroad. ${ }^{41}$ Taking into account the spouses and children, the number of beneficiaries in this area of aid under the GI Bill exceeded 21 million people (1944 to 1952) at a cost to the budget of 14.5 billion US dollars. ${ }^{42}$ As a result, 'for half a decade following the war veterans dominated the nation's campuses by their numbers and their academic superiority over nonveteran classmates.' ${ }^{43}$ According to the previously quoted D. Ravitch: 'No other society had ever subsidized so large and nonselective a portion of its population in institution of higher education. ${ }^{44}$ For the first time in US history, the relationship between wealth and the chances of getting a good education was interrupted. Estimates of the number of veterans who would have given up starting or continuing studies if not for the GI Bill of Rights were about 450-550,000 people. ${ }^{45}$ American historian Sidney Burell

\footnotetext{
${ }^{36}$ H. Herbold, op. cit., p. 107.

${ }^{37}$ R. Polenberg, One Nation Divisible: Class, Race, and Ethnicity in the United States Since 1938, Penguin Books, New York 1980, pp. 20-21.

${ }^{38}$ The federal government calculated basing on data from a survey that only between $8 \%$ and $12 \%$ of the veterans wanted to study full-time after the war (I.M. Conesa, A.D. Rubio, op. cit., p. 41).

${ }^{39}$ M. Bennett, op. cit., p. 201.

${ }^{40}$ M. Greenberg, The GI Bill of Rights [in:] Historians on America. Decisions That Made a Difference, ed. G. Clack, Dot1q Publishing, Washington 2010, p. 49.

${ }^{41}$ In 1950 under the GI Bill 5,800 veterans studied outside the US. Ibidem.

${ }^{42}$ J.W. Milton, For the Good of the Order: Nick Coleman and the High Tide of Liberal Politics in Minnesota, 1971-1981, Xlibris Corporation, Minnesota 2012, p. 134.

${ }^{43}$ K.W. Olson, The GI Bill and Higher Education: Success and Surprise, “American Quarterly" 1973, Vol. 25, No. 5, p. 596.

${ }^{44}$ D. Ravitch, op. cit., p. 14.

${ }^{45}$ Ibidem.
} 
assessed the Bill of Rights as 'the most important educational and social transformation in American history. ${ }^{46}$ Perhaps this judgment is exaggerated and too determined. One can undoubtedly say that the Bill was a good investment in the area of human resources. ${ }^{47}$

Moreover, its effects were immediate. While in 1940 the number of Americans who gained university degrees was 216,000 , in 1950 it was 497,000 people. ${ }^{48}$ In 1940 only $23 \%$ of soldiers held a high school diploma and $3 \%$ completed college. The Bill translated into education among the soldiers but significantly affected national statistics. In 1940 a total of 160,000 students graduated from college - in 1950 already 0.5 million. Mass participation in courses and systematic education not only increased the skills, making it easier to find a job but also evenly distributed over time the influx of millions of veterans into the labour market. Their absorption was therefore not abrupt, but adequate for the purchasing needs of society awakened and delayed in time by the war.

The second area covered by the provisions of the Bill was to facilitate applications for loans for veterans. The availability of loans was subject to conditions similar as with educational support (at least 90 days of service after September 16, 1940, and application within two years after they had left the army. State aid was limited to loans for the construction of houses, farms, their equipment or businesses (only in the US, not overseas). The repayment period could not exceed 20 years. For loans for the above goals, the US government acted as guarantor to repay half of the capital (but not more than \$2000). If instalments were not paid by the borrower, the government could file an appropriate claim against him or her. The new solution worked therefore in three ways: encouraged developers to build, bankers to lend, and the veterans to buy.

In addition, the government also financed the interest for the first year of the guaranteed portion of the loan. There was a condition: the interest rate could not exceed $4 \%$. The biggest advantage for veterans was the possibility of obtaining a higher loan amount or better terms and conditions (due to the government's guarantee of the half of repayment). Between 1944 and 1952 US government guaranteed repayment of 2.4 million loans to build a house for the amount of 16.5 billion dollars. ${ }^{49}$

The GI Bill of Rights made thousands of Americans owners of houses, apartments, and businesses. Before World War II to obtain a loan for the construction or purchase of a home was dependent on the possession of $50 \%$ of own contribution. The GI Bill successfully avoided this pitfall. Nearly 5 million veterans have benefited from this assistance. Every second new house built in the US in the first postwar decade was financed with a loan for veterans ${ }^{50}$. The result was not only the dynamic development of suburbs but also increased demand for cars (most of the

\footnotetext{
${ }^{46}$ S. Burrel, The G. I. Bill and the Great American Transformation, "Boston University Graduate Journal", Vol. 15, No. 3.

${ }^{47}$ D. Ravitch, op. cit., p. 15.

${ }^{48}$ J. Patterson, op. cit., p. 68.

${ }^{49}$ W.H. Young, N.K. Young, World War II and the Postwar Years in America, ABC-Clio, Santa Barbara 2010, p. 358; cf. W.L. O'Neill, op. cit., p. 10.

${ }^{50}$ E. Humes, op. cit., p. 99.
} 
new houses arose in the suburbs), household appliances, furniture, etc. By the end of 1947 US government guaranteed more than a million loans for the construction of homes and farms. While in 1944 the construction of 114,000 houses began, six years later, it was already 1.7 million. In total, until 1950 the Veterans Administration of the US government endorsed the construction of over two million homes. ${ }^{51}$ Nearly 28 percent of the World War II veterans have used VA home loans. ${ }^{52}$ The new buildings were the driving force for local businesses. They stimulated the growth of cities and through the need to build new streets have changed their topography. New shopping centres emerged, as well as new offices, schools, and churches. The rate of construction of new buildings was spectacular as if to make up for time lost during the war.

Another provision of the GI Bill introduced unemployment benefits. They could be granted for a maximum of one year and only veterans residing permanently in the United States were eligible. The period of unemployment had to fall within the period of two years from the end of the war or demobilisation. ${ }^{53}$ It was allowed to collect benefits with part employment, however, earnings on this account could not exceed 23 dollars per week. The weekly benefit amount was \$20. In the case of part-time work, the amount of the benefit was subject to reduction by the surplus of weekly earnings over 3 dollars. The legislator also stipulated that the collection of benefits for the unemployed within the framework of separate state programs reduces the amount of the benefit provided by the Bill. The length of the benefit period was dependent on the length of army service after September 16, 1940. During the first three months of service it was converted, a month of service equals eight weeks of benefit, and for the next months, starting from the fourth - four weeks of benefit. Due to the limit of 52 weeks of collecting benefits, it followed that the service of more than 10 months did not result in the extension of the period of entitlement to benefits. ${ }^{54}$

Payment of benefits could be withheld in a number of cases. These included: leaving a job without a valid reason, dismissal from work due to a serious misconduct, resignation from participation in training, cessation of work during a dispute between employer and employees, failure to take work commissioned by the local employment office (the conditions of the offer could not be worse than the average for the place of residence of the unemployed, one could not also be required to work in the plant during a strike or lockout). The Bill also provided limited support for the self-employed (this provision also included farmers). If the monthly business profits did not exceed $\$ 100$, it was possible to apply for a settlement, equal to the difference between the monthly profit and $\$ 100$. This aid could be used for up to 12 months. In the case of farmers, due to the nature of activities and profitability

\footnotetext{
${ }^{51}$ M. Greenberg, The GI Bill of Rights [in:] Historians on America. Decisions That Made a Difference, Washington 2010, p. 50.

${ }^{52}$ Findings and Recommendations. Veterans' Benefits in the United States. A Report to the President by the President's Commission on Veteran`s Pensions, Washington 1956, p. 303.

${ }^{53}$ This provision was beneficial to veterans because the Bill was adopted while the hostilities were ongoing. Thus, following their conclusion, veterans were entitled to benefits calculated from the date of the end of the war.

${ }^{54}$ Veterans who were allowed $\$ 20$ a week for fifty-two weeks were called '52-20 Club.'
} 
dependent on the seasons, profits were compared on an annual basis. The self-employed people in the agricultural sector or other, in the event of bankruptcy of the company were entitled to a 'standard' \$20 unemployment benefit. As it turned out, the pool reserved for government grants for veterans was only $20 \%$ used. About half of those eligible applied for the benefit (even if in a smaller amount). ${ }^{55}$ In the end, only $14 \%$ of veterans took advantage of the full amount. ${ }^{56}$

The last area of assistance under the GI Bill was help in finding a job. For this purpose, the Veterans Placement Service Board was established, which was to cooperate with the United States Employment Service. ${ }^{57}$ Its importance - as in the case of unemployment benefits - was small. The American economy easily absorbed consecutive thousands of demobilised soldiers.

The GI Bill of Rights was a federal program funded by the central funds. It contained, however, the mechanism by which the funds followed the applicant (formally they found their way directly to the institution, but it was the candidate who had the greatest influence on where the funds would go). This solution stimulated competition among schools and banks. Incidentally, at the stage of discussion in Congress, educational institutions supported option in which the allocation of funds remained at the level of schools, which would then, having the appropriations, be free to formulate the recruitment principles for candidates. The solution eventually adopted proved to be so effective that it works in the American education still today, as indeed the whole system of benefits for veterans. ${ }^{58}$ An important advantage of the implemented regulations was a skilful combination of a social component (financing and public guarantees) with the promotion of activity, responsibility for one's decisions and the requirement to cope with the new post-war reality. The new houses built with the government funds had not been waiting for soldiers returning from the battlefield. They themselves had to take care of the construction of these houses. The location of the future home was not determined by an anonymous government agency but selected according to the capabilities and needs of former soldiers. It was to promote active attitudes among the population, particularly reinforced by the fact that the dwellings became veterans' private property.

\footnotetext{
${ }^{55}$ M. Greenberg, op. cit., p. 49.

${ }^{56}$ S. Mettler, The Creation of the G.I. Bill of Rights of 1944: Melding Social and Participatory Citizenship Ideals, "Journal of Policy History 2005, Vol. 17, No. 4, p. 345.

${ }^{57}$ In 1949, the tasks of the Veterans Service Board were taken over by the Department of Labor (United States Code, Vol. 2, Washington 2008, p. 560).

${ }^{58}$ None of the other aid programs for veterans was so generous for that group, as the 1944 original act. For example, the regulations adopted after the war in Korea provided funding tuition fees at $51 \%$. D.J. Spaulding, The Four Major GI Bills: A Historical Study of Shifting National Purposes and the Accompanying Changes in Economic Values to Veterans. Unpublished doctoral dissertation, http://digital.library.unt.edu/ark:/67531/metadc2692/m2/1/high_res_d/dissertation.pdf (accessed: July 24, 2016).
} 


\section{Closing remarks}

When adopting the GI Bill of Rights, it was expected that unemployment benefits would be the most important and consequential area of the Bill's impact. Post-war American society had undergone a major transformation and as a result of access to cheaper home loans and more democratic - i.e. available not only to the richest access to education. ${ }^{59}$ As Paul Simon pointed: 'the G. I. Bill helped transform the nation from a hierarchical society sharply divided by wealth and class to one where citizens aspired and reached middle-class status. ${ }^{\prime 60}$ The Bill strengthened Roosevelt's and later Truman's position, who easily showed how different were the new solutions from those adopted after WWI. Therefore, an American researcher Suzanne Mettler is right when she says that the program helped foster a civil society, creating the image among veterans that the government was willing to care for them ${ }^{61}$.

The GI Bill of Rights is mentioned among the most important acts of the American legislation on social affairs. In the American political discourse, it functions as a prime example of reasonable spending of public money. Indeed, it was the largest federal program ever undertaken to provide financial assistance to individuals in continuing their education and training. ${ }^{62}$ Its results were profound. Hilary Herbold estimates that "military personnel who used their benefits to complete a college degree or vocational training program earned an average of $\$ 10,000$ to $\$ 15,000$ more annually than those who had not. ${ }^{\prime 63}$ Additionally, these increased earnings have generated tax revenues eight to ten times greater than the total cost of the program. According to one of the congressional analysis 'for every dollar the government invested in education under the GI Bill, the nation received at least $\$ 5$ of benefits and as much as $\$ 12.50$ of benefits. ${ }^{64}$ It is no surprise that it is called the best investment the U.S. government has ever made.

\section{References}

Bennett M., When Dreams Came True: The GI Bill and Making of Modern America, Brassey 2000.

Blair J., GI Bill Paved the Way for a Nation of Higher Learners, "Education Week" 1999, Vol. 18, Issue 20, p. 32.

\footnotetext{
${ }^{59}$ In 1946, American colleges and universities enrolled 2.1 million candidates for the first year of study ( 0.5 million more than the previous year; veterans accounted for $48.7 \%$ (and $71.5 \%$ if we take only men into account). M. Bennett, op. cit., p. 2.

${ }^{60}$ P. Simon, A GI Bill for Today, "Chronicle of Higher Education" 2003, No. 50, p. 16.

${ }^{61}$ S. Mettler, op. cit., p. 367.

${ }^{62}$ Findings and Recommendations..., p. 287.

${ }^{63}$ H. Herbold, op. cit., p. 104.

${ }^{64}$ Hearings before the Subcommittee on Education and Health of the Joint Economic Committee Congress of the United States. One Hundredth Congress. Second Session. December 14 and 15, 1988, Washington 1989 , p. 8.
} 
Boulton M., Failing our Veterans. The GI Bill and the Vietnam Generation, New York University Press, New York 2014.

Burrel S., The G. I. Bill and the Great American Transformation, "Boston University Graduate Journal", Vol. 15, No. 3.

Conesa I.M., A.D. Rubio, The Consequences of a Forced Migration: The Return Home of WWII American Veterans, "Advances in Historical Studies" 2016, Vol. 5, p. 36.

Dickson P., T.B. Allen, The Bonus Army. An American Epic, Walker and Company, New York 2004.

Findings and Recommendations. Veterans' Benefits in the United States. A Report to the President by the President's Commission on Veteran's Pensions, Washington 1956.

Greenberg M., The GI Bill of Rights [in:] Historians on America. Decisions That Made a Difference, ed. G. Clack, Dot1q Publishing, Washington 2010.

Hearings before the Subcommittee on Education and Health of the Joint Economic Committee Congress of the United States. One Hundredth Congress. Second Session. December 14 and 15, 1988, Washington 1989.

Herbold H., Never a Level Playing Field: Blacks and the GI Bill, "The Journal of Blacks in Higher Education" 1994, Vol. 6, p. 104.

Hershberg J.G., James B. Conant. Harvard to Hiroshima and the Making of the Nuclear Age, Stanford University Press, California 1993.

Humes E., Over Here. How the G. I. Bill Transformed the American Dream, Harcourt, New York 2006.

Hutchins R.M., The Threat to American Education, "Collier's Weekly”, December 30, 1944.

Johnson H., The Negro Veteran Fights for Freedom!, "Political Affairs" 1947, No. 5, p. 430.

Mason H.M., VFW: Our First Century, Addax Publishing Group, Lenexa 1999.

Mettler S., The Creation of the G.I. Bill of Rights of 1944: Melding Social and Participatory Citizenship Ideals, "Journal of Policy History" 2005, Vol. 17, No. 4, p. 345.

Milton J.W., For the Good of the Order: Nick Coleman and the High Tide of Liberal Politics in Minnesota, 1971-1981, Xlibris Corporation, Minnesota 2012.

Mosch T.R., The GI Bill: A Breakthrough in Educational and Social Policy in the United States, Exposition Press, New York 1975.

Olson K.W., The GI Bill and Higher Education: Success and Surprise, "American Quarterly" 1973, Vol. 25, No. 5, p. 596.

O'Neill W.L., American High. The Years of Confidence 1945-1960, The Free Press, New York 1986.

Ortiz S.R., Beyond the Bonus March and GI Bill. How Veteran Politics Shaped the New Deal Era, New York University Press, New York 2010.

Patterson J., Great Expectations. The United States 1945-1974, Oxford University Press, Oxford 1996.

Polenberg R., One Nation Divisible: Class, Race, and Ethnicity in the United States Since 1938, Penguin Books, New York 1980.

Public Papers of the Presidents of the United States, Vol. 12, 1943.

Ravitch D., The Troubled Crusade. American Education 1945-1980, Basic Books, Washington 1983.

Simon P., A GI Bill for Today, "Chronicle of Higher Education” 2003, No. 50, p. 16. 
Smith W., T. Bender, American Higher Education Transformed, 1940-2005 Documenting the National Discourse, The Johns Hopkins University Press, Baltimore 2008.

Spaulding D.J., The Four Major GI Bills: A Historical Study of Shifting National Purposes and the Accompanying, http://digital.library.unt.edu/ark:/67531/metadc2692/m2/1/ high_res_d/dissertation.pdf

The Bill of Rights and How It Works, Army Times, Washington 1944.

The Congressional Record, Vol. 91, Washington 1947.

Thomas S.M., Education in Wisconsin 1922-1924, Callahan, Wisconsin 1924.

Tucker S.C., World War II. The Definite Encyclopedia and Document Collection, Vol. 2, ABC-CLIO, Santa Barbara 2016.

United States Statutes at Large, United States Printing Office, Washington 1945, 1946, 2008.

Van Ells M.D., To Hear Only Thunder Again. America`s World War II Veterans Come Home, Lexington Books, Oxford 2011.

Waller W., The Veteran Comes Back, Dryden, New York 1944.

Young W.H., N.K. Young, World War II and the Postwar Years in America, ABC-Clio, Santa Barbara 2010. 